ELORE (ISSN 1456-3010), vol. $18-1 / 2011$.

Julkaisija: Suomen Kansantietouden Tutkijain Seura ry.

[http://www.elore.fi/arkisto/1_11/kirjat_leppalahti.pdf]

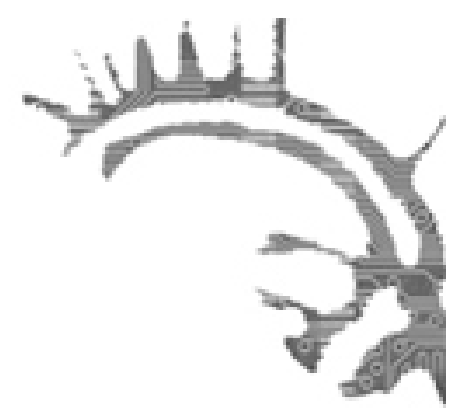

\title{
KIRJA-ARVIO
}

\section{UUTUUKSIA MYÖTÄ- JA VASTAVIRTAAN}

MIKKOLA, KATI 2009: Tulevaisuutta vastaan. Uutuuksien vastustus, kansantiedon keruu ja kansakunnan rakentaminen. Helsinki: SKS. 423 sivua.

\section{Merja Leppälahti}

Uudistukset nähdään usein kehityksen edellytyksenä ja täten myönteisinä ilmiöinä. Myös tutkimuksissa nostetaan helposti esille edelläkävijöitä ja menestystarinoita. Kati Mikkola tekee väitöskirjassaan tässä poikkeuksen, sillä hän keskittyy siihen, miten ja millaisin perusteluin uutuuksia vastustettiin 1800-luvun lopulla ja 1900-luvun alkupuolella. Tutkimuksen aineisto koostuu Suomalaisen Kirjallisuuden Seuran vuonna 1939 järjestämän Miten kansa vastaanotti undet elämänmuodot? -kyselyyn lähetetyistä 84 vastauksesta, itse kyselystä, vastaajien ja arkiston välisestä kirjeenvaihdosta sekä vastaajien elämäkerrallisista teksteistä.

\section{KySEly JA VASTAAjaT}

Mikkola käsittelee poikkeuksellisen laajasti tutkimusaineistonsa syntyprosessia ja sen taustaa; tämä ei ole pelkästään aineiston kuvaamista vaan myös tärkeä osa tutkimusta. Hän tarkastelee erikseen keruukyselyn taustaa kartoittamalla 1930-luvun lopun yhteiskunnallista ja kulttuurista ilmapiiriä sekä kyselyn laatijan Esko Aaltosen aate- ja toimintamaailmaa. Aaltonen kuului Suomen yhteiskunnallisiin ja kulttuurisiin vaikuttajiin: hänen aloitteestaan syntyi esimerkiksi tunnettu keskustelukirja Pidot tornissa (1937), jossa Aaltonen esiintyi nimellä Lehtimies. Suomalainen kansanelämä ja kansanluonne kuuluivat Aaltosen keskeisiin kiinnostuksenkohteisiin. Miten kansa vastaanotti undet elämänmuodot? -kyselyn teemat ja kysymykset muotoutuivat nimenomaan Aaltosen ihanteiden, tutkimusintressien ja esiymmärryksen pohjalta. Hänen toimintansa on siis vaikuttanut ratkaisevasti siihen, että tutkimuksen aineisto on juuri sellainen kuin se on. 
Kysely itsessään poikkesi hieman aikaisemmista Kansantieto-lehdessä julkaistuista kyselyistä. Kansantieto on Suomen ainoa, ennen toista maailmansotaa julkaistu lehti, jossa kartoitetaan nimenomaan yhteiskunnallisia muutosprosesseja. Useimmiten kyselyissä pyrittiin keräämään tietoa erityisesti kansanperinteen osa-alueista, kuten vanhoista tavoista ja uskomuksista, siis haluttiin tallentaa menneeseen painottuvaa perinneainesta ennen sen painumista unholaan.

Kyselyn vastaajat olivat kansanperinteen harrastajakerääjiä eri puolelta Suomea, ja aineistossa ovat edustettuina kaikki Suomen suomenkieliset perinnealueet. Vastaajista 57 oli miehiä, 27 naisia, iältään he edustivat monia ikäryhmiä alle 20-vuotiaista yli 80 -vuotiaisiin. Mukana oli hyvin monen eri ammatin harjoittajia. Myös koulutustasoltaan vastaajat olivat monenlaisia: osa oli täysin kouluttamattomia mutta mukana oli myös yliopistossa opiskelleita. Useat vastaajista lähettivät toistuvasti kokoamaansa perinneaineistoa arkistoon, erityisesti Kansantieto-lehdessä julkaistujen kyselyjen pohjalta.

Miten kansa vastaanotti undet elämänmuodot? -kyselyssä nimettyjä uudistuksia olivat muun muassa uudet viljelytavat ja rakennusmuodot, sanomalehtien ja muun kirjallisuuden lukeminen ja koulunkäynti, iltamien ja valistustilaisuuksien alkaminen, rahan käyttö, muutokset talon tai perheen tavoissa, uudenlaiset vaateparret sekä politisoituminen ja puolue-elämä. Kyselyssä mainittujen uudistusten lisäksi vastaajat kertoivat muistakin muutoksista, kuten uusista liikenne- ja viestintäyhteyksistä, arkisten toimintojen koneellistumisesta ja metsästyksen muutoksesta. Kysely on kokonaisuudessaan julkaistu osana Mikkolan väitöskirjaa, sivuilla 26-27. Sen olisi voinut julkaista myös erillisenä liitteenä, jolloin se olisi ollut helppo löytää myöhemminkin.

\section{UUDISTUSTEN VASTUSTUS}

Miksi uudistuksia sitten vastustettiin ja kuka niitä vastusti? Mikkolan aineistossa uutuuksien vastustajiksi nimetään hiukan muita useammin "vanhat ihmiset" ja "uskovaiset", mutta kaiken kaikkiaan vastustajien joukko oli hyvin heterogeeninen. Mikkola toteaa, että vastustus oli usein eräänlaista muutosvastarintaa, joka perusteltiin tarpeella säilyttää olemassa oleva säädetty järjestys. Tämä järjestys oli sekä hengellistä että maallista. Kirkollisen, uskonnollisen argumentin mukaan mikä tahansa entisestä poikkeava saatettiin tulkita synniksi ja siten yksiselitteisesti vääräksi. Rukiin puolustajat pitivät uusia viljelyskasveja jumalanviljan häpäisynä, koneissa arveltiin olevan piru mukana toimimassa tai niitä pidettiin muuten Jumalan luoman järjestyksen vastaisina. Uskonnon ja ei-uskonnon rajaa ei aina ollut helppo nähdä. Mikkola mainitsee esimerkiksi erilaiset valistustilaisuudet, joihin osa yleisöä tuli virsikirjat mukanaan ja "akat" saattoivat poistua kiukkuisina kesken tilaisuuden, kun puhuja ei ollutkaan pappi, eikä tilaisuudessa puhuttu "Herran sanaa" vaan höpötettiin maallisia.

Toinen tavallinen muutosten vastustamisen argumentti pohjautui perinteiseen sääty-yhteiskunnan roolijakoon. Eri yhteiskuntaluokkiin kuuluvilla ihmisillä oli omat paikkansa yhteiskunnassa, eikä tätä tilannetta sopinut sekoittaa. Esimerkiksi koulunkäynti ja lukeminen yleensäkin saatettiin nähdä rahvaan ja talonpojan lapselle turhana ja jopa haitallisena, sillä koulujen käyminen tuotti herroja, eikä herraksi oppineesta 
lukumiehestä enää kunnon töihin olisi. Usein vastustusta perusteltiin molemmilla tavoilla. Esimerkiksi uusmuotiset vaatteet saattoivat itsessään olla jumalattomat ja niiden käytössä saattoi piillä synnillistä koreilunhalua; sellaisten käyttäjä saattoi myös leimautua siveettömäksi ja sillä tavoin syntiseksi. Tämän lisäksi uudenlaiset vaatteet myös rikkoivat sääty-yhteiskunnan roolijakoa, kun rahvas jäljitteli pukeutumisessaan herroja. Mielenkiintoista on, että myös uutuuksien puolustajat saattoivat käyttää aivan samoja argumentteja puolustaessa näkökantojaan: toisen kammoksuma pirun vehje saattoi olla toiselle elämää helpottava Jumalan lahja, ja uudistukset saattoivat tarjota mahdollisuuden sosiaaliseen nousuun ja parempaan elämään.

\section{MYÖtÄ- JA VASTAVIRTAAN}

Keruun aikaan niissä tarkastellut uudistukset olivat jo toteutuneet, joten niiden vastustajat olivat jo hävinneet taistelunsa. Mikkola kuvaakin aineistotekstien sisältämää kaksinkertaista ironiaa, kun mennyttä tarkastellaan takautuvasti jo toteutuneen valossa. Kerääjät suhtautuivat hyvin myönteisesti perinteeseen ja näkivät vaivaa sen keräämiseksi ja tallentamiseksi. Kuitenkin myös he olivat näiden tekstien mukaan tavallisessa arjessa pääosin uudistusten kannattajia; perinteen paikka oli arkistossa, ei elävässä elämässä. Aineistoteksteissä kansantiedon kerääjät nousevatkin esiin valistuneina henkilöinä, jotka tarkastelevat "kansaa" - erityisesti juuri näitä uudistusten vastustajia - sen ylä- tai ulkopuolelta. Oikeastaan vain politisoituminen ja puolue-elämä nostivat myös kerääjissä esille kohtalaisesti vastarintaa, kun useissa kirjoituksissa valitettiin niiden tuomaa epäsopua ja kaipailtiin entistä yhtenäistä onnelaa.

Mikkolan keskeinen tutkimusmenetelmä on lähiluku, mutta hän ottaa huomioon myös aineiston ulkoiset seikat vastausten ohjaajina. Esimerkiksi se, että vastaajia tavallisesti pyydettiin keräämään selkeästi kansanperinneaineistoa, ohjasi monia heistä myös tässä kyselyssä kuvailemaan kansatieteellisiä yksityiskohtia. Mikkola käsittelee myös kyselyn sanamuotoa vastauksiin vaikuttaneena tekijänä. Varsinaisia kerättyjä aineistoja Mikkola lukee kahteen suuntaan: myötä- ja vastavirtaan. Myötävirtaan lukemisessa hän pyrkii tavoittamaan kirjoittajan näkökulmaa ja tulkitsee sitä suopeasti, gadamerilaisittain hyvän tahdon mukaisesti. Vastavirtaan lukiessaan Mikkola taas pyrkii tarttumaan uutuuksien vastustajien näkemysten taustalla oleviin perusteluihin. Hän "raaputtaa historian ironiaa" ja etsii kirjoittajien huvittuneidenkin kommenttien takaa uudistusten vastustajien ajattelun ja toiminnan rationaalisuutta.

Mikkola tarkastelee työssään laajasti paitsi 1800-luvun lopun ja 1900-luvun alkupuolen modernisoitumista ja sekularisoitumista, myös kansantiedon keruuta ja siihen vaikuttaneita seikkoja juuri ennen toista maailmansotaa. Uutuuksien vastustamisen ohella Mikkola käsittelee samalla myös kansanperinteen määrittelyn valtaa. Arkiston tallettama aineisto oli lähtöisin kansalta, mutta kansantietouden harrastajakerääjien vallassa oli suodattaa sitä, mitä he keräsivät ja lähettivät arkistoon. Kansarunousarkiston työntekijät puolestaan ohjasivat kerääjiä paitsi kirjoituspyynnöin, myös toisinaan hyvinkin selkein ohjeistuksin siitä, mikä oli kyllin arvokasta kerättäväksi ja tallennettavaksi, mikä taas ei. 
Merja Leppälahti: Uutuuksia myötä- ja vastavirtaan

\section{KirjallisuUs}

KIVIMIES, Yrjö (toim.) 1937: Pidot tornissa. Jyväskylä: Gummerus.

Filosofian lisensiaatti Merja Leppälahti on turkulainen folkloristi. 